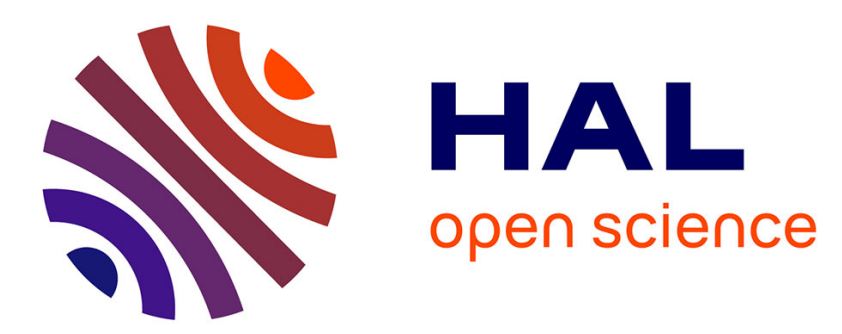

\title{
Satellite-based high latitude snow volume trend, variability and contribution to sea level over 1989/2006
}

Sylvain Biancamaria, Anny Cazenave, Nelly Mognard, W. Llovel, Frédéric Frappart

\section{- To cite this version:}

Sylvain Biancamaria, Anny Cazenave, Nelly Mognard, W. Llovel, Frédéric Frappart. Satellite-based high latitude snow volume trend, variability and contribution to sea level over 1989/2006. Global and Planetary Change, 2011, 75 (3-4), pp.99-107. 10.1016/j.gloplacha.2010.10.011 . hal-00575518

\section{HAL Id: hal-00575518 https://hal.science/hal-00575518}

Submitted on 10 Mar 2011

HAL is a multi-disciplinary open access archive for the deposit and dissemination of scientific research documents, whether they are published or not. The documents may come from teaching and research institutions in France or abroad, or from public or private research centers.
L'archive ouverte pluridisciplinaire HAL, est destinée au dépôt et à la diffusion de documents scientifiques de niveau recherche, publiés ou non, émanant des établissements d'enseignement et de recherche français ou étrangers, des laboratoires publics ou privés. 


\section{contribution to sea level over 1989/2006}

3

4 5 and Frédéric Frappart ${ }^{4}$

6

7

8

9

10

11

${ }^{4}$ Université de Toulouse; UPS (OMP-SVT); LMTG; 14 Av. Edouard Belin, F-31400

12

Toulouse, France

13

14

15

16

17

18

19

20

21

22

23

24 * Corresponding author: sylvain.biancamaria@legos.obs-mip.fr (Phone: +335 613329 30;

25 Fax: +3356125 32 05) 
Microwave/Imager (SSM/I) radiometric measurements for all land surfaces above $50^{\circ} \mathrm{N}$,

except Greenland. The mean annual snow volumes over the whole study domain, Eurasia and North America are respectively equal to $3713 \mathrm{~km}^{3}, 2272 \mathrm{~km}^{3}$ and $1441 \mathrm{~km}^{3}$, for the Pan

Arctic regions, over this 18 -year time period. While the snow volume exhibits a statistically significant negative trend $\left(-9.7 \pm 3.8 \mathrm{~km}^{3}\right.$.year ${ }^{-1}$, p-value=0.02) over North America, it presents

34 a positive, but not statistically significant trend $\left(11.3 \pm 9.3 \mathrm{~km}^{3} \cdot \mathrm{year}^{-1}, \mathrm{p}\right.$-value $\left.=0.25\right)$ over

Eurasia. These opposite variations can be related to different regional climatic conditions over these two regions: over Eurasia, snow depth is mainly influenced by the Arctic Oscillation $(\mathrm{AO})$ and the Atlantic Multidecadal Oscillation $(\mathrm{AMO})$ - correlation coefficient $=0.68$ between the SSM/I-derived snow volume and a linear combination of AO and AMO indices, whereas over North America snow depth is mainly influenced by the Pacific North American (PNA) pattern and the AMO - correlation coefficient $=0.75$ for a linear combination of the PNA and AMO indices. This study confirms that snow volume is a key driver of the sea level seasonal cycle, but net snow volume trend for the Pan Arctic regions indicates a negligible and not statistically significant contribution to sea level rise $\left(-0.004 \pm 0.009\right.$ mm.year ${ }^{-1}, \mathrm{p}-$ value $=0.88$ once converted into sea level). 
High latitude regions are the most affected by current climate change (e. g. Trenberth

et al., 2007). Different components of the Arctic hydrological cycle have experienced important modifications since the beginning of the $20^{\text {th }}$ century. For example river discharge has significantly increased (Stocker and Raible, 2005), snow extent is decreasing (Déry and Brown, 2007; Brown et al., 2010) and the annual duration of the period with unfrozen soil conditions has increased (Groisman et al., 2006). Snow volume is a key variable to understand the evolution of the high latitude hydrological cycle. High latitude rivers discharge is mainly driven by the accumulated snow volume and the timing of its melting, leading to extremely important floods in spring (Yang et al., 2003). So, snow cover extent and depth are among the Essential Climate Variables (ECV) of the Global Climate Observing System (GCOS; Sessa and Dolman, 2008) and observations of their temporal evolution are of critical importance. Few in situ snow observations are available at high latitude, thus providing limited information on global and regional snow depth fields (Brown, 2000). Remote sensing techniques complement the in situ data, but most analyses focused on snow extent change (see Trenberth et al., 2007 for a review), which only partially characterize snow variability. So far, interannual to multidecadal changes in snow volume have been mainly estimated using hydrological model outputs (e.g. Milly et al., 2003). In this study, we use satellite-based microwave observations to derive and analyze high latitude snow volume changes over 1989/2006. Correlations between snow volume and climate indices have been investigated and the Arctic snow contribution to the global mean sea level variation has been estimated. 
Snow volume used in this study has been computed from Special Sensor

74 Microwave/Imager (SSM/I) data. SSM/I measures the Earth brightness temperature for different microwave frequencies in both horizontal and vertical polarizations $(19.35 \mathrm{GHz}, 37$ GHz, 85.5 GHz and 22.235 GHz). Since July 1987, this instrument has been operating on board the operational Defense Meteorological Satellite Program satellite series. Daily SSM/I data, mapped to the Equal Area SSM/I Earth Grid projection with a $25 \times 25 \mathrm{~km}^{2}$ resolution, are provided by the National Snow and Ice Data Center (Armstrong et al., 1994). A dynamic algorithm that takes into account the temporal evolution of the snow grain size, developed by Mognard and Josberger (2002), has been used to retrieve snow depth from SSM/I measurements. This algorithm has been first developed for the U.S. Northern Great Plains, then amended by Grippa et al. (2004) and applied over Western Siberia. Recently, a multiyear (1988/1995) averaged snow depth field computed using this algorithm has been validated over Siberia (Boone et al., 2006) and the whole high latitude regions, Greenland excluded (Biancamaria et al., 2008). Interannual variability of these data has been validated over the $\mathrm{Ob}$ river basin, in Western Siberia, by comparison with discharge measurements at the estuary (Grippa et al., 2005). The latter study found a significant correlation between the snowmelt date and the discharge in May (correlation coefficient $=-0.92$ ) and between the winter snow depth and the discharge in June (correlation coefficient $=0.61$ ).

The inputs for this algorithm are the difference between $19.35 \mathrm{GHz}$ and $37 \mathrm{GHz}$ brightness temperature in horizontal polarization from SSMI, the air/snow interface temperatures from the National Centers for Environmental Prediction global (NCEP) reanalysis (Kalnay et al., 1996) and the snow/ground interface temperatures modeled by the "Interaction between Soil-Biosphere-Atmosphere" (ISBA) scheme forced by the Global Soil Wetness Project-Phase2 P3 precipitation field (Boone et al., 2006). For the present study, we consider all continental surfaces above $50^{\circ} \mathrm{N}$, Greenland excluded, composed of two sub- 
regions: Eurasia $\left(0^{\circ} \mathrm{E}<\right.$ longitude $\left.<191^{\circ} \mathrm{E}\right)$ and North America $\left(191^{\circ} \mathrm{E}<\right.$ longitude $\left.<360^{\circ} \mathrm{E}\right)$. Regions below $50^{\circ} \mathrm{N}$ have not been taken into account as the snowpack is highly variable spatially and of low amplitude, hence difficult to observe with a $25 \times 25 \mathrm{~km}^{2}$ spatial resolution. According to the snow climatology over North America from Brown et al. (2003), between December and March, $80 \%$ of the total North American snow volume is found above $50^{\circ} \mathrm{N}$. This study focuses on monthly and yearly-averaged total snow volume (sum of all non-zero snow depth pixels multiplied by the pixel area). Yearly averages are centered on winter months (i.e. the yearly average for year $\mathrm{n}$ corresponds to the temporal average from October year n-1 to September year n).

Snow volume derived from SSM/I measurements for January, and temporally averaged over 1989/2006, has been compared to the 1979/1996 climatology for North America from Brown et al. (2003) and to the global climatology from U.S. Air Force/Environmental Technical Applications Center (USAF/ETAC) (Foster and Davy, 1988). The correlation coefficient between snow depth from SSM/I and Brown et al. (2003) is 0.36. However most of the differences between the two datasets are found over regions covered with tundra, according to the snow classification from Liston and Sturm, 1998). For tundracovered regions ( $42 \%$ of North America), the correlation coefficient is equal to 0.20 , whereas over the remaining of North America the correlation coefficient is equal to 0.60 (the tundra covers $42 \%$ of North America). This result is consistent with the previous study by

Biancamaria et al. (2008), which found that the dynamic algorithm does not perform well over the Northern part of the continent (where the tundra is located) due to the presence of numerous lakes. The SSM/I data over these regions need to be processed using a specific algorithm, such as the one developed by Derksen et al. (2010), to take into account the specificity of snow emissivity over lakes. Yet, this still remains an open issue, which requires further investigations since, the in situ snow gauges, used by Brown et al. (2003) to compute a 
123 climatology by interpolation are very scarce above $50^{\circ} \mathrm{N}$, especially for the Northern part of

124 the continent. snow depth from SSM/I correlates better with the USAF/ETAC climatology

125 (correlation coefficient equals to 0.62 over the whole study domain, 0.67 over Eurasia and

1260.52 over North America ), These correlation coefficients are highly significant, as their p-

127 values (i.e. the probability to obtain these coefficients by random chance, whereas the

128 variables are uncorrelated) are extremely small (lower than 0.001). The snow depth retrieved

129 from SSM/I measurements are not directly compared to in situ measurements as the spatial

130 resolution of SSM/I is too coarse to be compared to local measurements, and high latitude

131 networks of in situ snow depth measurements are not dense enough to allow an estimation of

132 the mean snow depth over a $25 \times 25 \mathrm{~km}^{2}$ area. Based on a statistical analysis over the U.S.

133 Northern Great Plains, Chang et al. (2005) showed that error between one single in situ

134 measurement and the mean snow depth over a $1^{\circ} \times 1^{\circ}$ region can be up to $20 \mathrm{~cm}$ (for a range of 135 snow depth values between $1.5 \mathrm{~cm}$ and $45.4 \mathrm{~cm})$.

136 The temporal variability of the SSM/I-derived snow volume is analyzed in the next

137 section. It agrees well with previous published studies, giving high confidence in the quality

138 of the snow volume time series estimated from SSM/I observations.

1403 . Snow volume temporal variability

142 Figure 1 shows the monthly anomalies of snow volume time series averaged over the study

143 area from SSM/I, from an inversion of the Level-2 GFZ Gravity Recovery And Climate

144 Experiment (GRACE) products (Ramillien et al., 2005; Frappart et al., 2006), from the

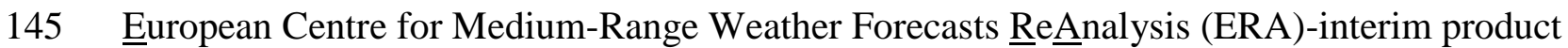

146 (Uppala et al., 2008), and outputs from two Land Surface Models (LSM) used by the Global

147 Land Data Assimilation System (GLDAS) (Rodell et al., 2004): MOSAIC (Koster and 
148 Suarez, 1996) and NOAH 2.7 (Chen et al., 1996), between January 2003 and June 2006. The

149 mass variations measured by GRACE have been converted into snow volume assuming a

150 constant snow volume density of $300 \mathrm{~kg} \cdot \mathrm{m}^{-3}$. The time variations of the snow volume are

151 dominated by the seasonal cycle. NOAH outputs present a better agreement with GRACE

152 data both in terms of amplitude and timing. Snow volume from SSM/I is in better agreement

153 with MOSAIC for the amplitude and with ERA-interim for the phase. However, all datasets

154 agree well in phase and their amplitudes have the same order of magnitude, except for ERA-

155 interim which seems to overestimate the amplitude. The GRACE land water and snow

156 solutions used in this study, are based on the development of geopotential harmonic

157 coefficients up to a degree 50, which correspond to a spatial resolution of $400 \mathrm{~km}$ (see

158 Frappart et al. (in press) for more details about this dataset). This leads to smaller amplitudes

159 and smoothes the temporal time series. Table 1 presents the annual snow volume trends over

160 2003/2006 computed from SSM/I-based snow depth, from the snow reservoir extracted from

161 GRACE measurements and from the total GRACE signal over the whole study domain,

162 Eurasia and North America. Two trends computed from GRACE data are shown: the first one

163 has been directly computed from the GRACE (snow and total) time series and the second one

164 has been corrected from the Post-Glacial Rebound (PGR) trend estimated by Paulson et al.

165 (2007), available on the GRACE Tellus website (http://grace.jpl.nasa.gov). The uncertainties

166 on PGR trends are supposed to be around 20\% (Paulson et al., 2007) and are given in

167 mm.year ${ }^{-1}$ of equivalent water thickness, which have been converted into snow volume trends

168 using a constant snow density of $300 \mathrm{~kg} \cdot \mathrm{m}^{-3}$. The PGR trend (in equivalent snow volume per

169 year) is equal to $495.6 \mathrm{~km}^{3}$.year ${ }^{-1}, 31.2 \mathrm{~km}^{3} \cdot \mathrm{year}^{-1}$ and $464.4 \mathrm{~km}^{3} \cdot \mathrm{year}^{-1}$ over the whole study

170 domain, Eurasia and North America, respectively. SSM/I and PGR corrected GRACE trends

171 are all negative, as previously observed at basin-scale for the GRACE data by Frappart et al.

172 (in press), yet they are statistically significant only over North America. The differences 
173 between SSM/I and GRACE trends are likely caused by the sensitivity due to the small

174 number of years available for the computation, the truncation of the GRACE data (which

175 caused a loss of energy in the short spatial wavelengths) and PGR uncertainty.

176 Interannual total snow volume time series (seasonal signal removed) from SSM/I has

177 been computed over 1989/2006 for the whole study domain (Figure 2a) and separately for

178 Eurasia (Figure 2b) and for North America (Figure 2c). Table 2 presents the mean, standard

179 deviation and trend (with the p-value) of the SSM/I-based snow volume over 1989/2006.

180 ERA-interim data has not been used because of biases in the background forecast and in the

181 assimilated observations that makes them unreliable for trend estimation (Trenberth et al.,

182 2007). Even if an effort has been undertaken to reduce the biases in ERA-interim (Dee and

183 Uppala, 2009), trends computed with this dataset should still be used with caution. Outputs

184 from GLDAS are not shown, due to the presence of an obvious bias in these datasets between

185 the 1989/1999 and 2000/2006 time periods. For NOAH, the mean snow volume and standard

186 deviation over 1989/1999 are equal to $6239 \mathrm{~km}^{3}$ and $329 \mathrm{~km}^{3}$, respectively, whereas over

$1872000 / 2006$ they are equal to $4760 \mathrm{~km}^{3}$ and $183 \mathrm{~km}^{3}$, respectively. Thus, trends computed from

188 these snow depth fields will mainly be the result of this bias.

$189 \mathrm{SSM} / \mathrm{I}$ snow volume over Eurasia displays a positive, but not statistically significant,

190 trend of $11.3 \pm 9.3 \mathrm{~km}^{3} \cdot$ year $^{-1}$ (p-value $=0.25$, Figure $2 \mathrm{~b}$ ), while over North America the trend is

191 negative and statistically significant $\left(-9.7 \pm 3.8 \mathrm{~km}^{3} . \mathrm{year}^{-1}, \mathrm{p}\right.$-value $=0.02$, Figure $\left.2 \mathrm{c}\right)$. Trends

192 have been computed using the generalized linear model regression (Dobson, 1990), and the

193 uncertainty given with each trend corresponds to the standard error on the estimation of the

194 slope from the linear regression algorithm used. These uncertainties are high as snow volume

195 time series have large variability. When the yearly snow volume is averaged over the whole

196 study domain, the trend is positive, remains small, with a very large uncertainty and is not

197 statistically significant $\left(1.5 \pm 10.5 \mathrm{~km}^{3} \cdot \mathrm{year}^{-1}\right.$, $\mathrm{p}$-value $=0.88$, Figure $\left.2 \mathrm{a}\right)$. Figure 3 presents the 
regional distribution of snow depth trends over 1989/2006 (only statistically significant

199 trends, i.e. p-value<0.1, are shown). Over Eurasia, the highest positive trends are found over 200 the Lena basin, the southern part of the Yenisey basin (between $60^{\circ} \mathrm{N} / 70^{\circ} \mathrm{N}$ and $100^{\circ} \mathrm{E} / 130^{\circ} \mathrm{E}$ ) 201 and Eastern Europe. Over North America, Quebec, Baffin Island and the Arctic Ocean coast 202 show negative trends, whereas positive trends are found over the Rockies and Southern 203 Alaska. Previous studies interpolated sparse in situ measurements to infer temporal evolution 204 of snow cover. Groisman et al. (2006) analyzed 1811 in situ observations of the soil condition 205 (classified as frozen or unfrozen) between 1956 and 2004, within $11971^{\circ} \times 1^{\circ}$ grid cells over 206 the former Soviet Union (most of these grid cells containing only one in situ station). The in 207 situ network used is very sparse above $55^{\circ} \mathrm{N}$ and East of the Ural Mountains. Groisman et al. 208 (2006) observed a significant increase in the number of days with unfrozen soil conditions 209 between 1956 and 2004. Yet, this increase is most frequently due to a reduction of days with 210 frost and ice on the ground rather than a snow cover retreat. Besides, these modifications tend 211 to diminish during the last decade of the twentieth century. These observations agree with our 212 results (a positive, but not significant, snow volume trend over Eurasia). Bulygina et al. 213 (2009) used 820 in situ stations over Russia between 1966 and 2007 to infer snow depth trend 214 maps. They found that snow cover periods tend to be shorter, however the amount of snow 215 fall tends to increase, leading to positive snow depth trends over Eurasia: maximum storage 216 change increased from $0.2 \mathrm{~cm}$.year ${ }^{-1}$ to $0.6 / 0.8 \mathrm{~cm}$.year ${ }^{-1}$ (with maximum rates in Western 217 Siberia). These trends have the same order of magnitude than trends shown in Figure 3. Based 218 on in situ measurements, Kitaev et al. (2005) found a positive snow depth trend $\left(0.09 \mathrm{~cm}^{\text {.year }}\right.$ $219^{1}$ ) over Eurasia (for latitudes above $40^{\circ} \mathrm{N}$ ) for February between 1936/2000. This study also 220 showed opposite trends between snow water equivalent in February for 1966/2000 over 221 Eurasia and North America (the trends are equal to $0.743 \mathrm{~mm} /$ decade and -1.231743 $222 \mathrm{~mm} /$ decade, respectively). For February of the 1989/2006 time span, SSM/I-based snow depth 
trends are equal to $0.14 \mathrm{~cm} . y e a r^{-1}(\mathrm{p}-$ value $=0.15)$ over Eurasia and $-0.18 \mathrm{~cm}$. year $^{-1}(\mathrm{p}-$

224 value=0.02) over North America. These results are in agreement with the results found by

225 Kitaev et al. (2005).

Using different data sets (visible and microwave satellite observations, objective analyses of surface snow depth observations, reconstructed snow cover from daily temperature and precipitation, and proxy information derived from thaw dates), Brown et al. (2010) showed that snow cover extent in June and May respectively decreased by $46 \%$ and a $14 \%$ in the Arctic (latitude $>60^{\circ} \mathrm{N}$ ), during the $1967 / 2008$ time period. This reduction is observed over both Eurasia and North America and 56\% of snow cover extent variability for June and $49 \%$ for May is explained by air temperature. Using a less accurate data set, Déry and Brown (2007) showed that snow cover extent also decreased in Eurasia and North America during winter time for the 1972/2006 time span. However, the observed decline is smaller than during spring. The snow volume variability computed in our study does not seem to be consistent with the trend in snow cover extent observed in these previous studies, especially over Eurasia. Yet, this was expected. In effect, Ge and Gong (2008) showed that, at continental/regional scales, high latitude snow extent and snow depth are largely unrelated.

The decreasing trend of snow volume over North America estimated from SSM/I is in agreement with the previous study from Dyer and Mote (2006). Using interpolated in situ measurements during the 1960/2000 time span, they found that snow depth has a decreasing trend in January/February over the time period, which becomes even steeper around March, along with an earlier onset of spring thaw, which could explain the decreasing North American snow volume trend observed in our study.

It is extremely difficult to estimate the implications of the observed decreased in North American snow volume on other snow related parameters, like glaciers mass, and an answer to this issue is far beyond the scope of this paper. For example, very recently, Berthier et al. 
248 (2010) confirmed that Alaskan glaciers are losing mass. However, glaciers mass loss is not

249 only observed in North America, but is widely measured on all continents (Kaser et al., 2006).

250 Therefore, it is hard to assess if there is any relation between the Alaskan glaciers mass loss

251 and the decreasing snow volume in North America, and this issue will require further

252 investigations.

4. Relationship between snow volume and climate indices

To investigate the causes of snow volume variability in North America and Eurasia, yearly mean SSM/I snow volume anomaly has been correlated to climate indices representing the dominant modes of atmospheric and ocean variability. The following climate indices have been considered:

- Arctic Oscillation (AO, leading mode from the Empirical Orthogonal Function analysis of monthly mean height anomalies at $1000-\mathrm{hPa}$, poleward of $20^{\circ} \mathrm{N}$ ). A positive (negative) AO index corresponds to a lower (higher) than normal atmospheric pressure over the Artcic, which leads to stronger (weaker) westerly winds. Therefore, in positive AO phase, cold 264 Arctic air is maintained in the Northern part of America (Arctic coast and Quebec), while the rest of America, Europe and Asia experiences a warmer then averaged winter, with more precipitation in Northern Europe. On the contrary, in negative AO phase, cold Arctic air reaches lower latitude (South Canada, US, Asia and Europe), whereas the Northern parts of

268 America is warmer than during the positive AO phase (Thompson and Wallace, 1998).

269 - Atlantic Multidecadal Oscillation (AMO, North Atlantic mean sea surface temperature anomaly north of the equator). AMO corresponds to cycles of warming and cooling of the

271 North Atlantic Ocean with a period comprised between 50 and 80 years. This cycle affects the

272 North Atlantic branch of the thermohaline circulation and therefore the whole oceanic system 
273 (Kerr, 2000). A positive (negative) phase of the AMO leads to more (less) summer

274 precipitations in Northern Europe and Alaska and less (more) summer precipitations in the

275 U.S. and South Canada (Enfield et al., 2001). Knight et al. (2006) show, using a climate

276 model, that positive AMO phase tends to strengthen broad cyclonic pressure anomalies over

277 the Atlantic and Europe in winter, therefore increasing precipitations on these regions. During

278 the time span of the study (1989/2006), the AMO has shifted from a negative to a positive

279 phase around 1995.

280 - Pacific Decadal Oscillation (PDO, leading principal component of monthly sea surface

281 temperatures in the North Pacific, poleward of $20^{\circ} \mathrm{N}$ ). PDO is an El Niño-like pattern

282 characteristic the North Pacific climate variability with interannual to interdecadal

283 fluctuations. PDO influences mainly North America climate during winter time and is

284 positively correlated with precipitation along the coasts and central Gulf of Alaska and

285 negatively correlated over much of the interior of North America (Mantua et al., 1997).

286 - Pacific North American pattern (PNA, second component of the Northern Hemisphere extra

287 tropical sea level pressure anomalies). During positive (negative) phase of the PNA,

288 geopotential height anomalies are positive (negative) along the West coast of North America

289 and negative (positive) in the mid-Pacific and Eastern US. Therefore, negative PNA phase is

290 characterized by a strong East Asian jet stream, which is blocked during positive PNA phase.

291 The spatial scale of the PNA pattern is at its most extent during winter (Wallace and Gutzler,

292 1981).

293 Data have been computed by the National Oceanic and Atmospheric Administration

294 (NOAA)/Climate Prediction Center (CPC), the NOAA/Earth System Research Laboratory

295 (ESRL) and the Joint Institute for the Study of the Atmosphere and Ocean (JISAO)/University

296 of Washington (UW), and have been downloaded from 
http://ioc3.unesco.org/oopc/state_of the_ocean/atm. Each index has been averaged from

298 January through March for each year.

Figure 4 presents annual snow volume time series over Eurasia and North America

300 along with the January to March average of the climate indices presented above. As snow

301 volumes and the indices do not have the same units and range of variations, all time series

302 shown in Figure 4 have been normalized and centered. On each plot, the gray horizontal line

303 corresponds to the zero in the original climate index time series. Table 3 gives the correlation

304 coefficients between the climate indices and the annual snow volumes over North America

305 and Eurasia. The AO index is relatively well correlated with snow volume over North

306 America (correlation $=0.51$ and $p$-value $=0.03$, Figure $4 b$ ) and anti-correlated with snow

307 volume over Eurasia (correlation=-0.57 and p-value=0.01, Figure 4a), thus the climatic

308 conditions represented by the AO index (which is the dominant mode of interannual

309 variability in North Hemisphere) play a significant and opposite role over the two continents.

310 It is worth mentioning that SSM/I snow volume over Eurasia and North America are not

311 correlated (correlation $=-0.07$ and $p$-value $=0.80$ ). AMO and PNA are anti-correlated with

312 snow volume over North America (correlation $=-0.59$ with $\mathrm{p}$-value $=0.01$ and correlation $=-0.66$

313 with p-value $=0.003$, respectively) and not, or only weakly, correlated with snow volume over

314 Eurasia (correlation $=0.04$ with $p$-value $=0.88$ and correlation $=0.30$ with $p$-value $=0.22$,

315 respectively). On the contrary, PDO is more strongly linked with snow volume over Eurasia

316 (correlation=0.49 with p-value=0.04) than over North America (correlation=-0.18 with p-

317 value=0.47). Figure 5 presents snow depth linear regression maps based on each climate

318 index (i.e. the correlation coefficient between snow depth and the climate index multiplied by

319 the snow depth standard deviation for each pixel), which clearly show the locations where

320 snow depth co-varies with each climate index. On these maps, regression coefficients are

321 presented only for pixels which have a statistically significant ( $\mathrm{p}$-value $<0.1)$ correlation 
coefficient. Regression map between snow depth and AO index (Figure 5a) clearly shows the opposite impact of AO index over snow depth between North American Arctic coast and the Eastern part of Siberia (with positive regression coefficients) and middle Siberia and Eastern regression coefficients between snow depth and AMO index over Eurasia (Figure 5b), some negative regression coefficients over Quebec and North American Arctic coast and some 328 positive coefficients over the Rockies. Snow depth weakly co-varies with PDO index over 329 North America (Figure 5c), contrarily to Southern middle Siberia and Northeastern Europe, 330 where regression coefficients are positive. Finally, regression coefficients between snow 331 depth and PNA index (Figure 5d) show that PNA is linked with snow depth especially in 332 central North America (negative coefficients), in the Rockies (positive coefficients) and in 333 Southern middle Siberia (positive coefficients). From these results, it seems that AO is the 334 only mode affecting significantly snow volumes over both Eurasia and North America and 335 could explain the different behavior of snow volume over these two continents. Previous studies (Cohen et al., 2007; Orsolini and Kvamstø, 2009) have shown that

337 high snow cover in late autumn over Eurasia can create upward propagating planetary wave 338 pulses in winter, which weaken the polar vortex and therefore lead to negative AO in late 339 winter, explaining a negative correlation between snow cover extent and AO index. The same 340 process also explains the negative correlation between snow volume over Eurasia and winter 341 AO index observed in our study.

342 Ge and Gong (2009) compared monthly AO, NAO (North Atlantic Oscillation, 343 commonly seen as a regional manifestation of AO), PDO and PNA indices with monthly in 344 situ interpolated snow depth over North America during the 1956/2000 time span. They found 345 that snow depth has weak correlation with monthly AO and NAO indices, but strong anti346 correlation with monthly PDO and PNA indices for the winter months (December to April). 
347 However, for PDO, only correlation coefficients for February and March are significant at $34890 \%$ confidence level (for PNA all the correlations during all winter months are above the $34990 \%$ confidence level). Our results seem to differ partially, as we found that snow volume 350 significantly correlates with AO, significantly anti-correlates with PNA and has no significant 351 linear relationship with PDO over North America. However, it should be noted that Ge and 352 Gong (2009) studied a wider domain (with latitudes below $35^{\circ} \mathrm{N}$ ) and found the highest 353 relations between snow depth and PDO/PNA over interior central-western North America, 354 which expands far below $50^{\circ} \mathrm{N}$ (the Southern limit of our study domain). Ghatak et al. (2010) 355 used the same North American in situ-based snow depth field than Ge and Gong (2009) and 356 found that globally snow depths correlate negatively with both winter NAO and PNA. Yet, 357 their study domain includes the whole North American continent. If only the latitudes above $35850^{\circ} \mathrm{N}$ are considered (Figure 4 and 6 in Ghatak et al., 2010), they showed that snow depth 359 correlates positively with NAO and negatively with PNA, as found in our study (Table 3). 360 Their explanation of these correlations is the following: positive phase of winter NAO leads 361 to higher air temperature anomalies over eastern North America, reducing snow volume;

362 positive phase of the winter PNA leads to stronger East Asian jet stream and thus more 363 snowfall in Northwest America but to less snowfall in Northeast America and near the Arctic 364 coast (which is in agreement with the regression map between snow depth and PNA, Figure $3655 d)$.

To better examine inter-annual co-variability between snow volume and climate

367 indices, the linear trend in all time series has been removed and the corresponding correlation 368 coefficients have been computed (Table 3). Over Eurasia, the most statistically significant 369 correlations are still obtained with the $\mathrm{AO}$ (correlation $=-0.51$ with $\mathrm{p}$-value $=0.03$ ) and PDO 370 (correlation=0.41 with p-value=0.09) indices. Over North America, the only statistically 371 significant correlation is obtained with PNA index (correlation=-0.58 with p-value $=0.01$ ), 
372 which means that North American snow volume linear trend could be related to the AO and

373 AMO indices (probably due to the shift from a negative to a positive AMO around 1995),

374 whereas snow volume inter-annual variability is more linked with the PNA pattern.

The correlation coefficients between yearly mean snow volume anomaly and all possible linear combinations of two different climate indices have also been computed. For

377 Eurasia, the best correlation coefficient $(0.68$, p-value $=0.002)$ is obtained for a linear

378 combination between AO and AMO (-156.AO-611.AMO, blue curve in Figure 2b), whereas

379 for North America the best correlation coefficient $(0.75, \mathrm{p}$-value $<0.01)$ is obtained for a linear

380 combination between PNA and AMO (-235.AMO-92.PNA, blue curve in Figure 2c). AO and

381 PNA, when combined with AMO, influence respectively the most Eurasia and North America

382 snow volume and represent regional atmospheric processes influencing the two continents. If

383 the trend is removed from both climate indices and snow volume, the best correlation

384 coefficient is still obtained with a linear combination of AO and AMO indices over Eurasia (-

385 136.AO-940.AMO, correlation=0.68 and $\mathrm{p}$-value=0.002). Surprisingly, linear combination of

386 AO and PDO indices, which individually gives respectively the first (-0.51) and second (0.41)

387 best correlations with snow volume over Eurasia, only corresponds to the second best

388 correlation between a linear combination of two climate indices and snow volume (-

389 96.AO+76.PDO, correlation $=0.58$ and $p$-value $=0.01$ ). Over North America, the best

390 correlation is obtained with a linear combination of PDO and PNA indices (37.PDO-

391 114.PNA, correlation $=0.66$ and $p$-value $=0.003$ ), however the second best correlation is

392 obtained with AMO and PNA indices (-165.AMO-87.PNA, correlation=0.61 and p-

393 value=0.007).

394

395 5. Snow and sea level

396 
High latitude snow has a large impact on river discharge and thus is the main source of

398 fresh water input to the Arctic Ocean. Snow volume change $\left(\mathrm{V}_{\text {snow }}\right)$ presented in the previous 399 sections can be used to estimate the snow contribution to the global mean sea level ( $\left.\mathrm{SLV}_{\text {snow }}\right)$, 400 using equation (1).

401

402

$S L V_{\text {snow }}=-\frac{\rho_{\text {snow }}}{\rho_{\text {water }} \cdot A_{\text {ocean }}} \cdot V_{\text {snow }}$

403

404 where $\rho_{\text {snow }}=300 \mathrm{~kg} \cdot \mathrm{m}^{-3}$ (snow density), $\rho_{\text {water }}=1000 \mathrm{~kg} \cdot \mathrm{m}^{-3}$ (liquid water density) and $405 \quad \mathrm{~A}_{\text {ocean }}=3.6 \times 10^{8} \mathrm{~km}^{2}$ (total oceanic domain).

Over 1989/2006, the snow volume trend from SSM/I converted into equivalent sea

407 level is very small $\left(-0.0013 \pm 0.0087 \mathrm{~mm}_{\mathrm{yr}} \mathrm{yr}^{-1}\right)$ and not statistically significant. The snow

408 volume trend over the altimetry time span (1993/2006) amounts to $-17.0 \pm 15.1 \mathrm{~km}^{3} \cdot \mathrm{year}^{-1}(\mathrm{p}-$

409 value $=0.28$ ), which yield small positive contributions to sea level of $0.014 \pm 0.013 \mathrm{~mm} \cdot \mathrm{yr}^{-1}$. As

410 this trend is not statistically significant and is negligible compared to the global mean sea

411 level trend (of $3.3 \pm 0.4$ mm.yr ${ }^{-1}$ over the satellite altimetry period 1993/2009; Cazenave and

412 Llovel, 2010), it is obvious that high latitude snow does not play any role in the global mean

413 sea level rise observed from satellite altimetry.

414 However, Arctic snow is a key component of the mean sea level seasonal cycle. To

415 investigate this relationship, snow volume change has been compared to global mean sea level

416 time series over 2002/2006 from Topex/Poseidon and Jason 1 computed by Collecte

417 Localisation Satellite (CLS), available on the AVISO website (www.aviso.oceanobs.com).

418 The mean sea level data have been corrected for steric effects (mainly thermal expansion of

419 ocean waters) using the methodology developed by Llovel et al. (2010) and based on Argo

420 data (Guinehut et al., 2009). Mean and trend have been removed from this corrected sea level

421 and the seasonal cycle (i.e. the sinusoid with a 365.25 day period which best fits the time 
series) has been least square adjusted. The sea level seasonal cycle has a maximum amplitude of $6.2 \mathrm{~mm}$ which occurs around 15 October. Snow volume converted into sea level (mean and trend removed) has a seasonal cycle with $4.1 \mathrm{~mm}$ maximum amplitude around 10 August. Its amplitude is smaller, but has the same order of magnitude than the global mean sea level seasonal cycle, yet breaks earlier. This phase lag could be due to the time taken by water from snow melt to be routed to the ocean by the river network. It could also be explained if water stored in other reservoirs like ground water and water vapor in the atmosphere is taken into account. To test this hypothesis, the seasonal cycle of the ground water has been approximated by a sinusoid with amplitude of $3 \mathrm{~mm}$ (in sea level equivalent) and a yearly maximum at the beginning of September (Cazenave et al., 2000). Similarly, the atmospheric water vapor has been approximated by a sinusoid with amplitude of $2 \mathrm{~mm}$ and a yearly maximum at the beginning of December (Cazenave et al., 2000). The sum of these three contributors (snow, ground water and water vapor) has an amplitude equal to $6.9 \mathrm{~mm}$, which is very close to the global mean sea level seasonal cycle amplitude with a reduced phase lag (the maximum is around mid-September). This is a surprisingly good result given the large approximation used and clearly shows that Arctic snow variability is one of the main contributors to the global mean sea level seasonal cycle, as previously shown from model outputs by Chen et al. (1998), Minster et al. (1999), Cazenave et al. (2000) and Milly et al. (2003).

\section{Conclusions and perspectives}

From passive microwave data acquired between 1989 and 2006, it has been possible to estimate the high latitude snow volume variability. Over Eurasia, the mean annual snow volume trend is positive $\left(11.3 \pm 9.3 \mathrm{~km}^{3}\right.$.year $\left.{ }^{-1}\right)$, yet not statistically significant. Over North 
447 America the snow volume trend is equal to $-9.7 \pm 3.8 \mathrm{~km}^{3} \cdot$ year $^{-1}$ and is statistically significant.

448 This difference between the two continents could be due to AO which correlates with North

449 American snow volume (correlation $=0.51$ ) and anti-correlates with Eurasian snow volume

450 (correlation $=-0.57$ ). These differences are also linked with regional climatic conditions as

451 snow volume anomaly over North America better (anti-)correlates with the PNA index

452 (correlation=-0.66), and AMO index (correlation=-0.59). However, the correlation between

453 AMO and North American snow volume is mainly due to the trend and not to the interannual

454 variability. Moreover, snow volume over Eurasia correlates well with a linear combination of

455 the AO and AMO indices (correlation $=0.68$ ), whereas over North America it correlates with

456 a linear combination of the PNA and AMO indices (correlation $=0.75$ ).

457 Finally, this study shows that high latitude snow volume does not contribute to the

458 global mean sea level trend observed by satellite altimetry, but is a main component of the

459 global mean sea level seasonal cycle.

460 In the future, it will be interesting to compare the snow volume trends observed in this

461 study and trends from other hydrologic parameters in order to better understand the

462 interaction between snow and the whole North Hemisphere high latitude hydrological cycle.

463

464 Acknowledgments

465 The NSIDC is greatly thanked for processing and freely distributing SSM/I data.

466 The GLDAS data used in this study were acquired as part of the mission of NASA's Earth

467 Science Division and archived and distributed by the Goddard Earth Sciences (GES) Data and

468 Information Services Center (DISC). The Authors are thankful to J.-P. Vergnes for

469 downloading and post-processing GLDAS data.

470 ECMWF ERA-Interim data used in this study have been obtained from the ECMWF data

471 server. 
472 The NOAA/CPC, NOAA/ESRL and JISAO/UW are acknowledged for letting the time series

473 of the climate indices used in this study freely available to the community.

474 The authors are particularly grateful to two anonymous reviewers for their constructive

475 comments and suggestions, which significantly improved the quality of the manuscript.

476 Three of the authors are supported by a CNES/Noveltis PhD grant (S. Biancamaria), a STAE

477 foundation grant in the framework of the CYMENT project (F. Frappart) and a CNRS/Région

478 Midi-Pyrénées PhD grant (W. Llovel). 
Armstrong, R.L., Knowles, K.W., Brodzik, M.J., Hardman, M.A., 1994 (updated 2007).

DMSP SSM/I Pathfinder daily EASE-Grid brightness temperatures 1988-2006. National

Snow and Ice Data Center, Digital media, Boulder, Colorado USA.

484

Berthier, E., Schiefer, E., Clarke, G.K.C., Menounos, B., Rémy, F., 2010. Contribution of

Alaskan glaciers to sea-level rise derived from satellite imagery. Nat. Geosci., 3, 92-95.

487

Biancamaria, S., Mognard, N.M., Boone, A., Grippa, M., Josberger, E.G., 2008. A satellite snow depth multi-year average derived from SSM/I for the high latitude regions. Remote Sens. Environ., 112, 2557-2568.

491

Boone, A., Mognard, N.M., Decharme, B., Douville, H., Grippa, M., Kerrigan, K., 2006. The impact of simulated soil temperatures on the estimation of snow depth over Siberia from SSM/I compared to a multi-model multi-year average. Remote Sens. Environ., 101, 482-494.

Brown, R.D., 2000. Northern Hemisphere snow cover variability and change, 1915-97. J.

Brown, R.D., Brasnett, B., Robinson, D., 2003. Gridded North American monthly snow depth and snow water equivalent for GCM evaluation. Atmos. Ocean., 41, 1-14.

501

502 Brown, R.D., Derksen, C., Wang, L., 2010. A multi-data set analysis of variability and change 503 in Arctic spring snow cover extent, 1967-2008. J. Geophys. Res., 115, D16111. 
505 Bulygina, O.N., Razuvaev, V.N., Korshunova, N.N., 2009. Changes in snow cover over

506 Northern Eurasia in the last few decades. Environ. Res. Lett., 4, doi:10.1088/1748-

$5079326 / 4 / 4 / 045026$.

508

509 Cazenave, A., Remy, F., Dominh, K., Douville, H., 2000. Global ocean mass variation,

510 continental hydrology and the mass balance of Antarctica ice sheet at seasonal time scale.

511 Geophys. Res. Lett., 27, 3755-3758.

512

513 Cazenave, A., Llovel, W., 2010. Contemporary sea level rise. Annu. Rev. Mar. Sci., 2, 145-

514 173, doi:10.1146/annurev-marine-120308-081105.

515

516 Chang, A.T.C., Kelly, R.E.J., Josberger, E.G., Armstrong, R.L., Foster, J.L., Mognard, N.M., 517 2005. Analysis of ground-measured and passive microwave derived snow depth variations in 518 mid-winter across the Northern Great Plains. J. Hydrometeorol., 6, 20-33.

520 Chen, F., Mitchell, K., Schaake, J., Xue, Y., Pan, H.-L., Koren, V., Duan, Q.Y., Ek, M., Betts, 521 A., 1996. Modeling of land-surface evaporation by four schemes and comparison with FIFE 522 observations. J. Geophys. Res., 101, D3, 7251-7268.

524 Chen, J.L., Wilson, C.R., Chambers, D.P., Nerem, R.S., Tapley, B.D., 1998. Seasonal global 525 water mass budget and mean sea level variations. Geophys. Res. Lett., 25, 3555-3558.

527 Cohen, J., Barlow, M., Kushner, P.J., Saito, K., 2007. Stratopshere-Troposphere coupling and 528 links with Eurasian land surface variability. J. Clim., 20, 5335-5343. 
530 Dee, D.P., Uppala, S., 2009. Variational bias correction of satellite radiance data in the ERA-

531 interim reanalysis. Q. J. R. Meteorol. Soc., 135, 1830-1841.

532

533 Derksen, C., Toose, P., Rees, A., Wang, L., English, M., Walker, A., Sturm, M., 2010.

534 Development of a tundra-specific snow water equivalent retrieval algorithm for satellite 535 passive microwave data. Remote Sens. Environ., 114, 1699-1709.

536

537 Déry, S.J., Brown, R.D., 2007. Recent Northern Hemisphere snow cover extent trends and 538 implications for the snow-albedo feedback. Geophys. Res. Lett., 34, L22504.

539

540 Dobson, A.J., 1990. An introduction to generalized linear models. CRC Press, New York. 541

542 Dyer, J.L., Mote, T.L., 2006. Spatial variability and trends in snow depth over North America. 543 Geophys. Res. Lett., 33, L16503.

544

545 Enfield, D.B., Mestas-Nunez, A.M., Trimble, P.J., 2001. The Atlantic Multidecadal

546 Oscillation and its relationship to rainfall and river flows in the continental U.S.. Geophys.

547 Res. Lett., 28, 2077-2080.

548

549 Foster, D.J., Davy, R.D., 1988. Global snow depth multi-year average. USAFETAC/TN-

550 88/006, Illinois: Scott Air Force Base, 48 pp. 
552 Frappart, F., Ramillien, G., Biancamaria, S., Mognard, N.M., Cazenave, A., 2006. Evolution

553 of high-latitude snow mass derived from the GRACE gravimetry mission (2002-2004).

554 Geophys. Res. Lett., 33, L02501.

555

556 Frappart, F., Ramillien, G., Famiglietti, J.S., in press. Water balance of the Arctic drainage

557 system using GRACE gravimetry products. Int. J. Remote Sens., doi:

$558 \quad 10.1080 / 01431160903474954$.

559

560 Ghatak, D., Gong, G., Frei, A., 2010. North American temperature, snowfall, and snow-depth 561 response to winter climate modes. J. Clim., 23, 2320-2332.

562

563 Ge, Y., Gong, G., 2008. Observed inconsistencies between snow extent and snow depth 564 variability at regional/continental scales. J. Clim., 21, 1066-1082.

Ge, Y., Gong, G., 2009. North American snow depth and climate teleconnection patterns. J.

567 Clim., 22, 217-233.

568

569 Grippa, M., Mognard, N.M., Le Toan, T., Josberger, E.G., 2004. Siberia snow depth multi570 year average derived from SSM/I data using a combined dynamic and static algorithm.

571 Remote Sens. Environ., 93, 30-41.

572

573 Grippa, M., Mognard, N.M., Le Toan, T., 2005. Comparison between the interannual

574 variability of snow parameters derived from SSM/I and the Ob river discharge. Remote Sens.

575 Environ., 98, 35-44. 
577 Groisman, P.Y., Knight, R.W., Razuvaev, V.N., Bulygina, O.N., Karl, T.R., 2006. State of the 578 ground: climatology and changes during the past 69 years over Northern Eurasia for a rarely 579 used measure of snow cover and frozen land. J. Clim., 19, 4933-4955.

581 Guinehut, S., Coatanoan, C., Dhomps, A.-L., Le Traon, P.-Y., Larnicol, G., 2009. On the use 582 of satellite altimeter data in Argo quality control. J. Atmos. Oceanic Technol., 46, 85-98.

584 Kalnay, E., Kanamitsu, M., Kistler, R., Collins, W., Deaven, D., Gandin, L., Iredell, M., Saha, 585 S., White, G., Woollen, J., Zhu, Y., Chelliah, M., Ebisuzaki, W., Higgins, W., Janowiak, J., 586 Mo, K.C., Ropelewski, C., Wang, J., Leetmaa, A., Reynolds, R., Jenne, R., Joseph D., 1996. 587 The NCEP/NCAR 40-year reanalysis project. Bull. Am. Meteorol. Soc., 77, 437-471.

589 Kaser, G., Cogley, J.G., Dyurgerov, M.B., Meier, M.F., Ohmura, A., 2006. Mass balance of 590 glaciers and ice caps: Consensus estimates for 1961-2004. Geophys. Res. Lett., 33, L19501. 591

592 Kerr, R.A., 2000. A North Atlantic climate pacemaker for the centuries. Science, 288, 19845931986.

594

595 Kitaev, L., Førland, E., Razuvaev, V., Tveito, O.E., Krueger, O., 2005. Distribution of snow 596 cover over Northern Eurasia. Nord. Hydrol., 36, 311-319.

597

598 Knight, J.R., Folland, C.K., Scaife, A.A., 2006. Climate impacts of the Atlantic Multidecadal 599 Oscillation. Geophys. Res. Lett., 33, L17706.

600 
601 Koster, R.D., Suarez, M. J., 1996. Energy and water balance calculations in the Mosaic LSM,

602 NASA Tech. Memo. 104606, 9, 76 pp.

603

604 Liston, G.E., Sturm, M., 1998. Global Seasonal Snow Classification System. National Snow 605 and Ice Data Center Digital media, Boulder, CO, USA.

606

607 Llovel, W., Guinehut, S., Cazenave, A., 2010. Regional and interannual variability in sea 608 level over 2002-2009 based on satellite altimetry, Argo float data and GRACE ocean mass. 609 Ocean Dynam., 60, 1193-1204, doi:10.1007/s10236-010-0324-0.

610

611 Mantua, N.J., Hare, S.R., Zhang, Y., Wallace, J.M., Francis, R.C., 1997. A Pacific

612 interdecadal climate oscillation with impacts on salmon production. Bull. Am. Meteorol. Soc., $61378,1069-1079$.

614

615 Milly, P.C.D., Cazenave, A., Gennero, M.-C., 2003. Contribution of climate-driven change in 616 continental water storage to recent sea-level rise. Proc. Natl. Acad. Sci. U.S.A., 100, 13158$617 \quad 13161$.

618

619 Minster, J.F., Cazenave, A., Serafini, Y.V., Mercier, F., Gennero, M.-C., Rogel, P., 1999.

620 Annual cycle in mean sea level from Topex-Poseidon and ERS-1: inference on the global 621 hydrological cycle. Global Planet. Change, 20, 57-66.

622

623 Mognard, N.M., Josberger, E.G., 2002. Northern Great Plains 1996/97 seasonal evolution of 624 snowpack parameters from satellite passive-microwave measurements. Ann. Glaciol., 34, 1562523. 
627 Orsolini, Y.J., Kvamstø, N.G., 2009. Role of Eurasian snow cover in wintertime circulation:

628 Decadal simulations forced with satellite observations. J. Geophys. Res., 114, D19108.

629

630 Paulson, A., Zhong, S., Wahr, J., 2007. Inference of mantle viscosity from GRACE and 631 relative sea level data. Geophys. J. Int., 171, 497-508.

632

633 Ramillien, G., Frappart, F., Cazenave, A., Güntner, A., 2005. Time variations of the land 634 water storage from an inversion of 2 years of GRACE geoids. Earth Planet. Sci. Lett., 235, $635 \quad 283-301$.

636

637 Rodell, M., Houser, P.R., Jambor, U., Gottschalck, J., Mitchell, K., Meng, C.-J., Arsenault, 638 K., Cosgrove, B., Radakovich, J., Bosilovich, M., Entin, J.K., Walker, J.P., Lohmann, D., 639 Toll, D., 2004. The global land data assimilation system. Bull. Am. Meteorol. Soc., 85, 381640394.

641

642 Sessa, R., Dolman, H., 2008. Terrestrial Essential Climate Variables, GTOS n52, biennal 643 report supplement, 40 pp., FAO, Rome, Italy.

644

645 Stocker, T.F., Raible, C.C., 2005. Water cycle shifts gear. Nature, 434, 830-833.

646

647 Thompson, D.W.J., Wallace, J.M., 1998. The Arctic Oscillation signature in the wintertime 648 geopotential height and temperature fields. Geophys. Res. Lett., 25, 1297-1300

649 
650 Trenberth, K.E., Jones, P.D., Ambenje, P., Bojariu, R., Easterling, D., Klein Tank, A., Parker,

651 D., Rahimzadeh, F., Renwick, J. A., Rusticucci, M., Soden, B., Zhai, P., 2007. Observations:

652 Surface and Atmospheric Climate Change. In Climate change 2007: the physical science

653 basis. Contribution of Working Group I to the Fourth Assessment report of the

654 Intergouvernmental Panel on Climate Change, edited by S. Solomon et al., pp. 235-336 and

655 SM.3-8, Cambridge Univ. Press, Cambridge, U. K.

656

657 Uppala, S., Dee, D., Kobayashi, S., Berrisford, P., Simmons, A., 2008. Towards a climate

658 data assimilation system: status update of ERA-Interim. ECMWF newsletter, 115, 12-18.

659

660 Wallace, J.M., Gutzler, D.S., 1981. Teleconnections in the geopotential height field during the

661 Northern Hemisphere winter. Mon. Wea. Rev., 109, 784-812.

662

663 Yang, D., Robinson, D., Zao, Y., Estilow, T., Ye, B., 2003. Streamflow response to seasonal

664 snow cover extent changes in large Siberian watersheds. J. Geophys. Res., 108, 4578, doi:

$66510.1029 / 2002 J D 003419$. 
Table captions:

667

668 Table 1. Annual snow volume trends over 2003/2006 computed from SSM/I snow volume,

669 snow reservoir extracted from GRACE and from the total GRACE signal over the whole

670 study domain, Eurasia and North America

671

672 Table 2. Mean, standard deviation and trend of annual snow volume retrieved from SSM/I

673 measurements during 1989/2006 period over the whole study domain, Eurasia and North

674 America; p-values (p) for trends are indicated in parentheses.

675

676

Table 3. Correlation coefficients from January to March average of the climate indices (AO,

677

AMO, PDO and PNA) and annual snow volumes over North America and Eurasia (the p-

678

value of each correlation is indicated in parentheses). The correlations are computed both with

679 and without trend in the time series of both snow volume and climate indices.

680

681

682 Figure captions:

683

684 Figure 1. Total snow volume for all continental surfaces above $50^{\circ} \mathrm{N}$ (Greenland excluded)

685 estimated from SSM/I (red curve), GRACE (orange curve), ERA-interim reanalysis (black

686 curve), MOSAIC model (green curve) and NOAH model (blue curve).

687

688 Figure 2. Annual snow volume from SSM/I data (solid red curve) over the whole study

689 domain (a.), over Eurasia (b.) and over North America (c.). On each plot the black line

690 corresponds to the linear trend and the blue curve corresponds to the linear combination of 
691 two climate indices (January to March average) which best correlates with SSM/I snow

692 volume (the mean value of the SSM/I snow volume over the 1989/2006 period has been

693 added to the linear combination).

694

695 Figure 3. Map of the annual snow depth trends over the 1989/2006 time span. Only

696 statistically significant trends are shown (i.e. trends with p-value $<0.1$ ).

697

698 Figure 4. Annual snow volume over Eurasia (red curves in a., b., c., d.) and over North

699 America (red curves in e., f., g., h.) and January to March average of AO (blue cruves in a.,

700 e.), AMO (blue cruves in b., f.), PDO (blue cruves in c., g.) and PNA (blue cruves in d., h.)

701 indices versus time. The time series have been normalized and centered to be plotted at the

702 same scale. On each plot, the gray horizontal line corresponds to the zero in the original

703 climate index time series.

704

705 Figure 5. Regression maps between annual snow volume and January to March average of

706 AO (a.), AMO (b.), PDO (c.) and PNA (d.) indices for the 1989/2006 time span. On each map

707 are shown pixels with a statistically significant $(\mathrm{p}$-value $<0.1)$ correlation coefficient between

708 snow volume and the considered climate index. 
Tables:

Table 1:

\begin{tabular}{llllll}
\hline & \multicolumn{4}{c}{ Annual snow volume trend for 2003/2006 $\left(\mathrm{km}^{3} \cdot \mathrm{year}^{-1}\right)$} \\
& SSM/I & $\begin{array}{l}\text { GRACE snow } \\
\text { no PGR corr. }\end{array}$ & PGR corr. & $\begin{array}{l}\text { GRACE total } \\
\text { no PGR corr. }\end{array}$ & PGR corr. \\
\hline Whole domain & $\begin{array}{l}-71.4 \pm 83.5 \\
(\mathrm{p}=0.48)\end{array}$ & $\begin{array}{l}46.8 \pm 103.4 \\
(\mathrm{p}=0.70)\end{array}$ & -448.8 & $\begin{array}{l}179.0 \pm 234.3 \\
(\mathrm{p}=0.52)\end{array}$ & -316.6 \\
\hline Eurasia & $\begin{array}{l}-20.0 \pm 82.8 \\
(\mathrm{p}=0.83)\end{array}$ & $\begin{array}{l}-91.3 \pm 57.5 \\
(\mathrm{p}=0.25)\end{array}$ & -122.5 & $\begin{array}{l}-237.2 \pm 231.4 \\
(\mathrm{p}=0.41)\end{array}$ & -268.4 \\
\hline North America & $-51.4 \pm 9.6$ & $\begin{array}{l}138.1 \pm 46.2 \\
(\mathrm{p}=0.10)\end{array}$ & -326.3 & $\begin{array}{l}416.3 \pm 52.0 \\
(\mathrm{p}=0.02)\end{array}$ & -48.1 \\
\hline
\end{tabular}

Table 2:

\begin{tabular}{llll}
\hline & \multicolumn{3}{c}{ SSM/I annual snow volume } \\
& Whole domain & Eurasia & North America \\
\hline $1989 / 2006$ mean $\left(\mathrm{km}^{3}\right)$ & 3713 & 2272 & 1441 \\
\hline Std $\left(\mathrm{km}^{3}\right)$ & 218 & 189 & 95 \\
\hline Trend $\left(\mathrm{km}^{3} \cdot\right.$ year $\left.^{-1}\right)$ & $1.5 \pm 10.5(\mathrm{p}=0.88)$ & $11.3 \pm 9.3(\mathrm{p}=0.25)$ & $-9.7 \pm 3.8(\mathrm{p}=0.02)$ \\
\hline
\end{tabular}

709

710

711

712

Table 3 :

\begin{tabular}{|c|c|c|c|c|c|}
\hline & & $\mathrm{AO}$ & AMO & $\mathrm{PDO}$ & PNA \\
\hline \multirow{2}{*}{$\begin{array}{l}\text { Eurasian snow } \\
\text { depth }\end{array}$} & with trend & $\begin{array}{l}-0.57 \\
(\mathrm{p}=0.01)\end{array}$ & $\begin{array}{l}0.04 \\
(\mathrm{p}=0.87)\end{array}$ & $\begin{array}{l}0.49 \\
(p=0.04)\end{array}$ & $\begin{array}{l}0.30 \\
(\mathrm{p}=0.22)\end{array}$ \\
\hline & without trend & $\begin{array}{l}-0.51 \\
(p=0.03)\end{array}$ & $\begin{array}{l}-0.33 \\
(\mathrm{p}=0.18)\end{array}$ & $\begin{array}{l}0.41 \\
(p=0.09)\end{array}$ & $\begin{array}{l}0.21 \\
(\mathrm{p}=0.39)\end{array}$ \\
\hline \multirow{2}{*}{$\begin{array}{l}\text { North American } \\
\text { snow depth }\end{array}$} & with trend & $\begin{array}{l}0.51 \\
(\mathrm{p}=0.03)\end{array}$ & $\begin{array}{l}-0.59 \\
(p=0.01)\end{array}$ & $\begin{array}{l}-0.18 \\
(p=0.47)\end{array}$ & $\begin{array}{l}-0.66 \\
(p=0.003)\end{array}$ \\
\hline & without trend & $\begin{array}{l}0.25 \\
(\mathrm{p}=0.31)\end{array}$ & $\begin{array}{l}-0.31 \\
(p=0.20)\end{array}$ & $\begin{array}{l}0.10 \\
(p=0.71)\end{array}$ & $\begin{array}{l}-0.58 \\
(p=0.01)\end{array}$ \\
\hline
\end{tabular}


714 Figures:

715

Figure 1:

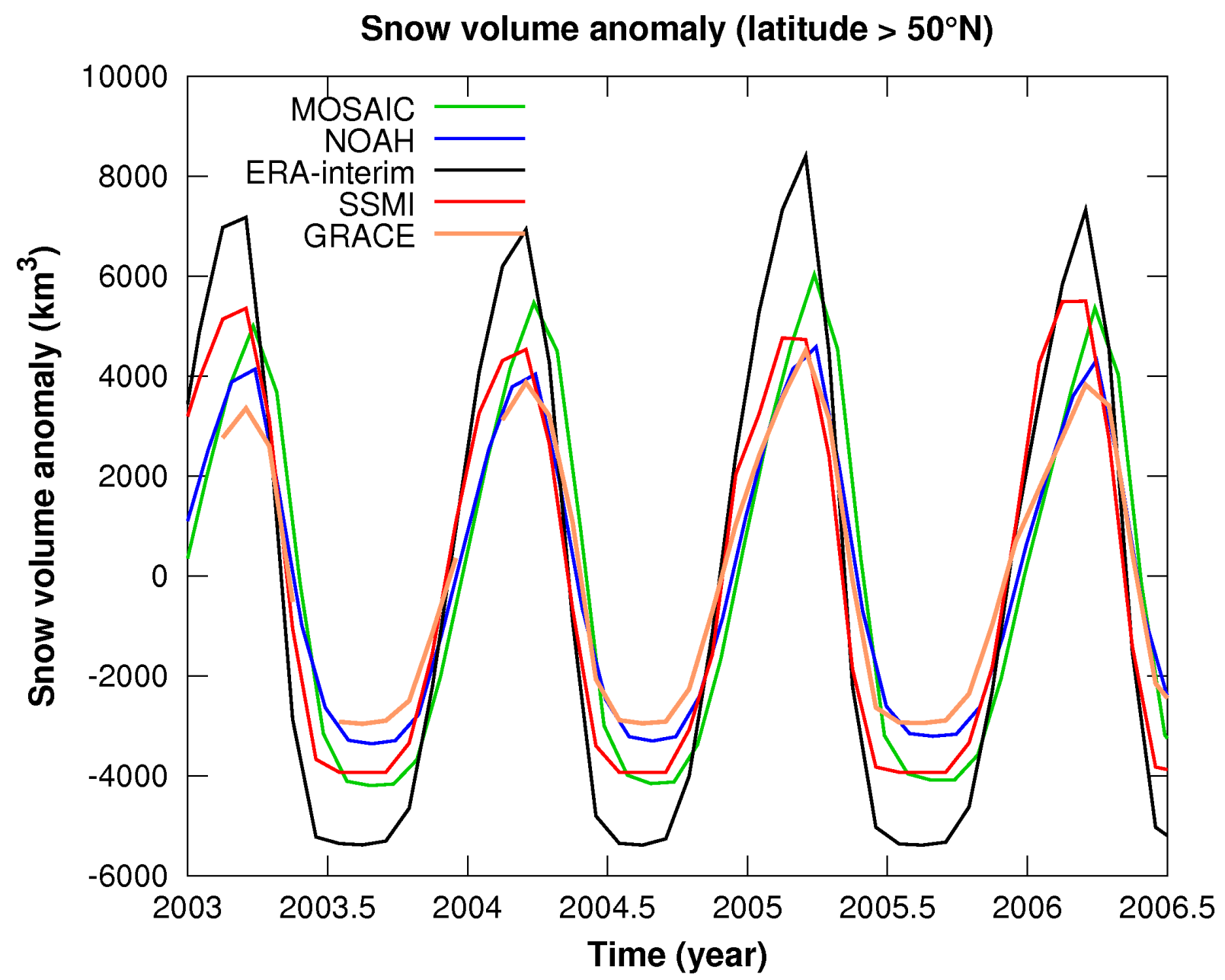


Figure 2:
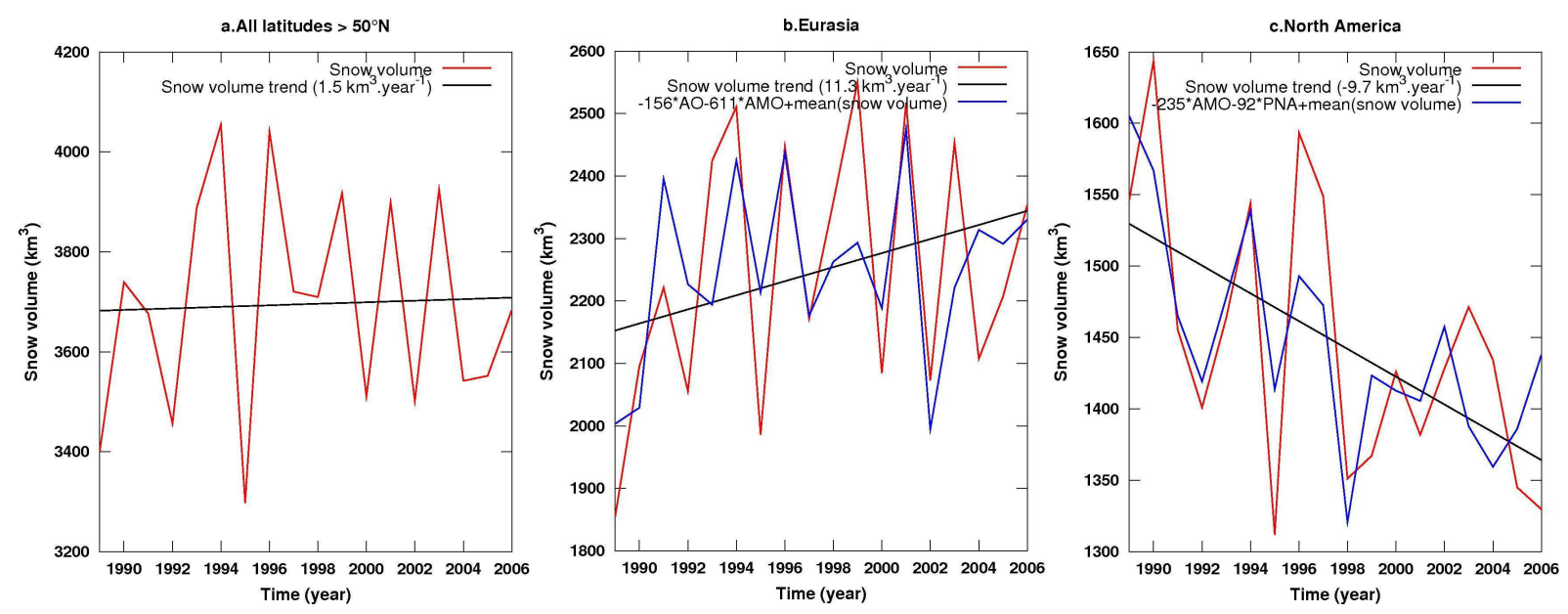
Figure 3:

SSM/I snow depth trend (1989/2006)

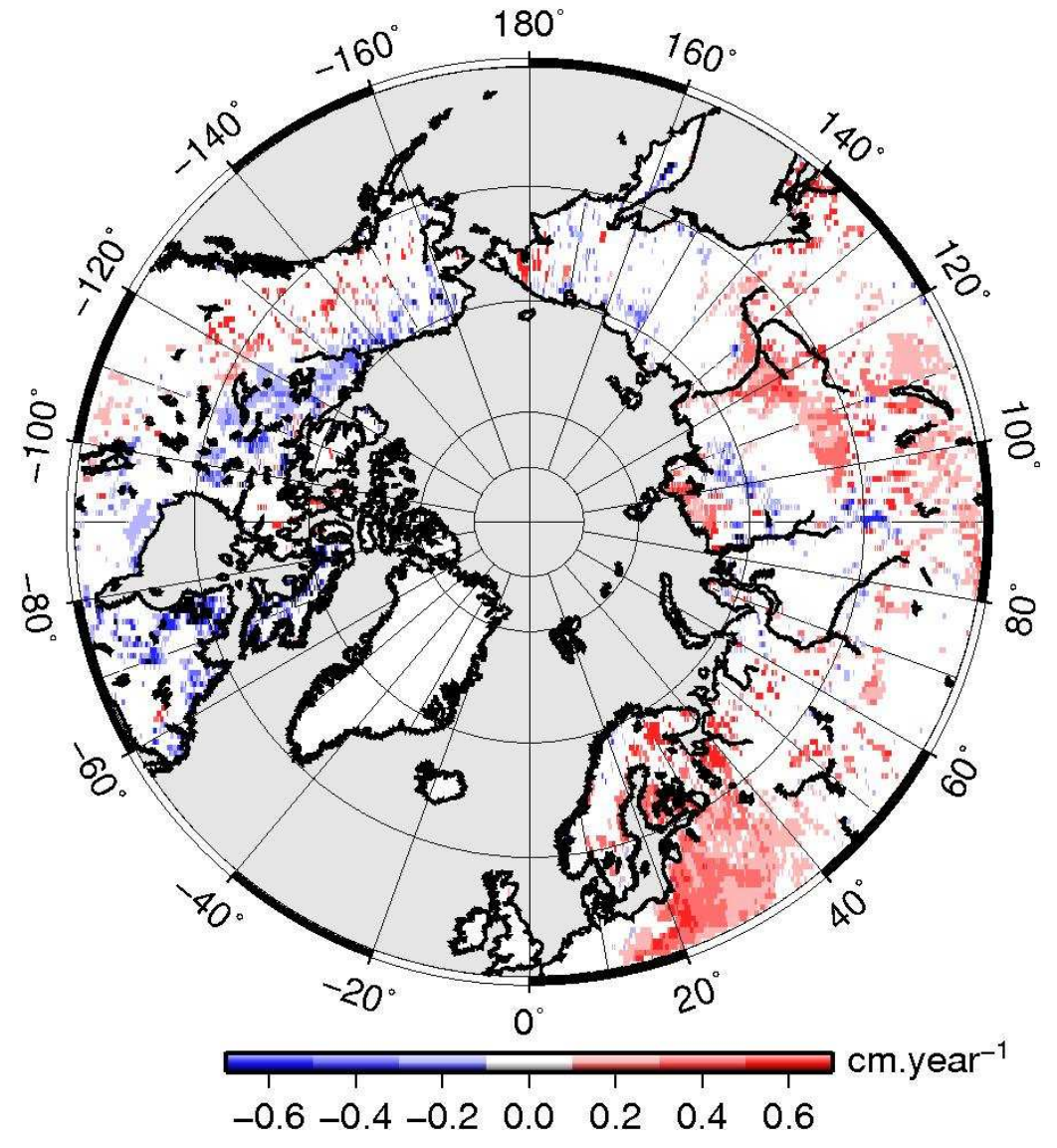


Figure 4 :
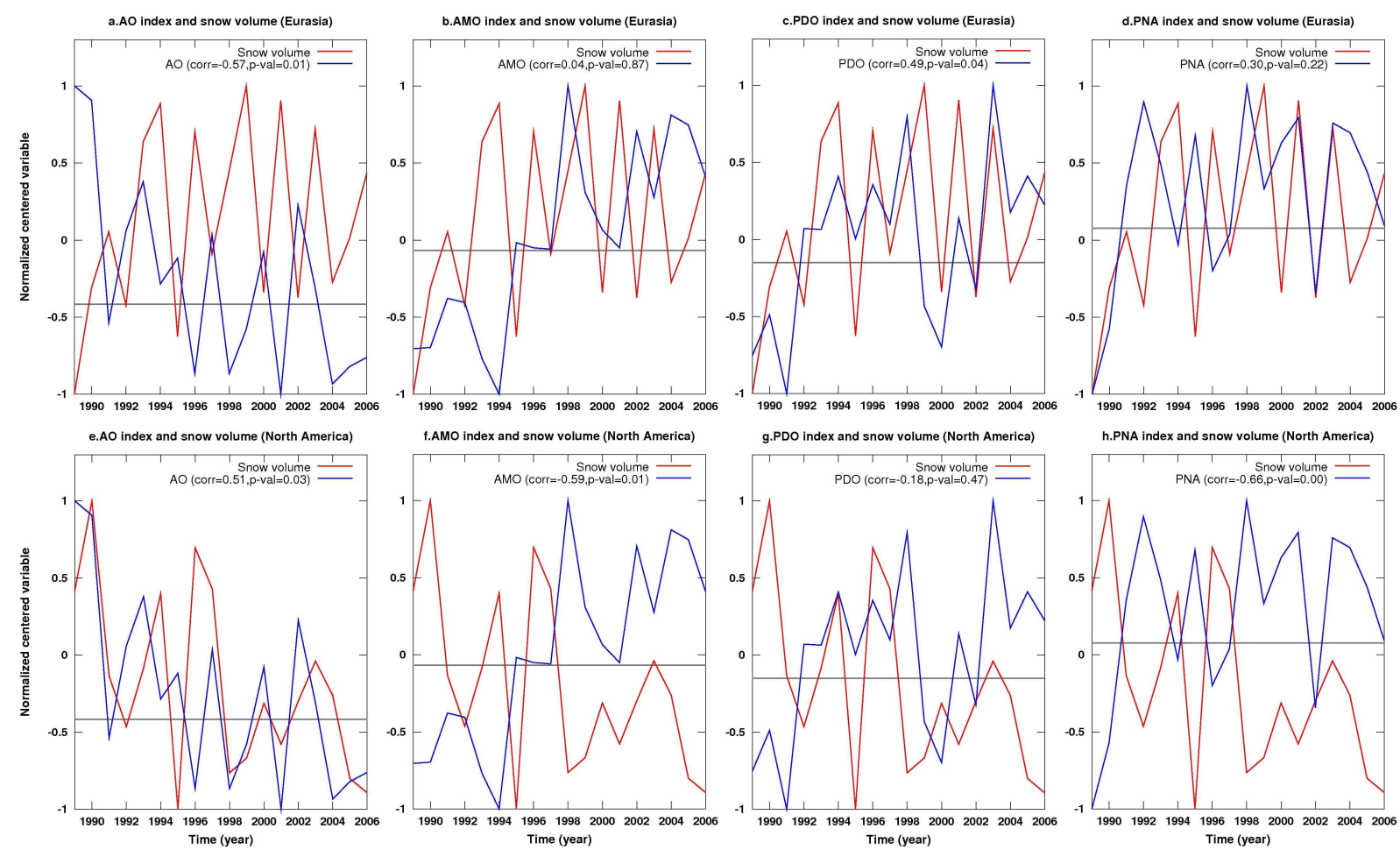
Figure 5:

a. Regression map Snow Depth/AO b. Regression map Snow Depth/AMO
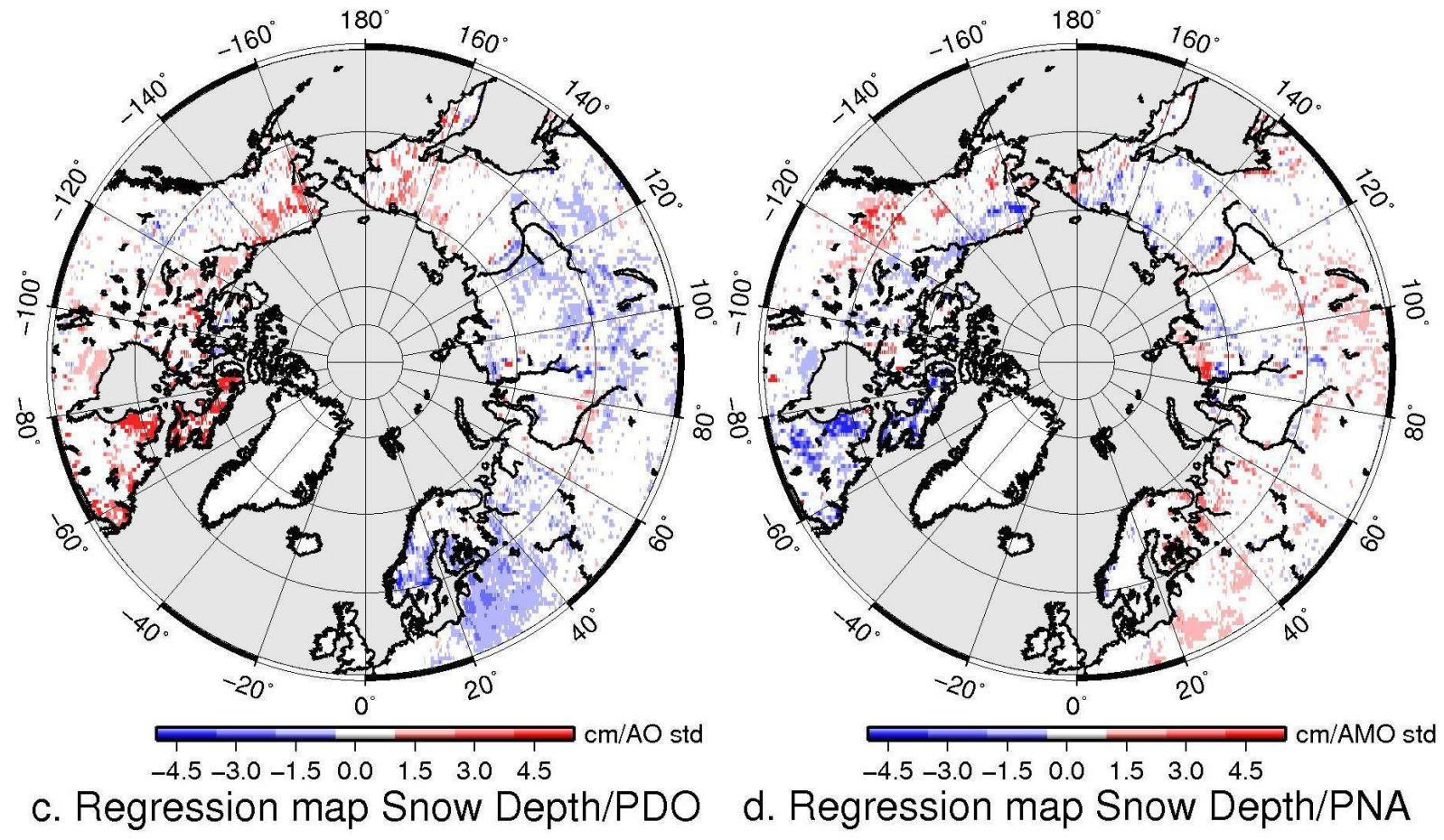

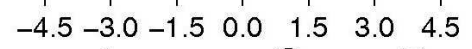

d. Regression map Snow Depth/PNA
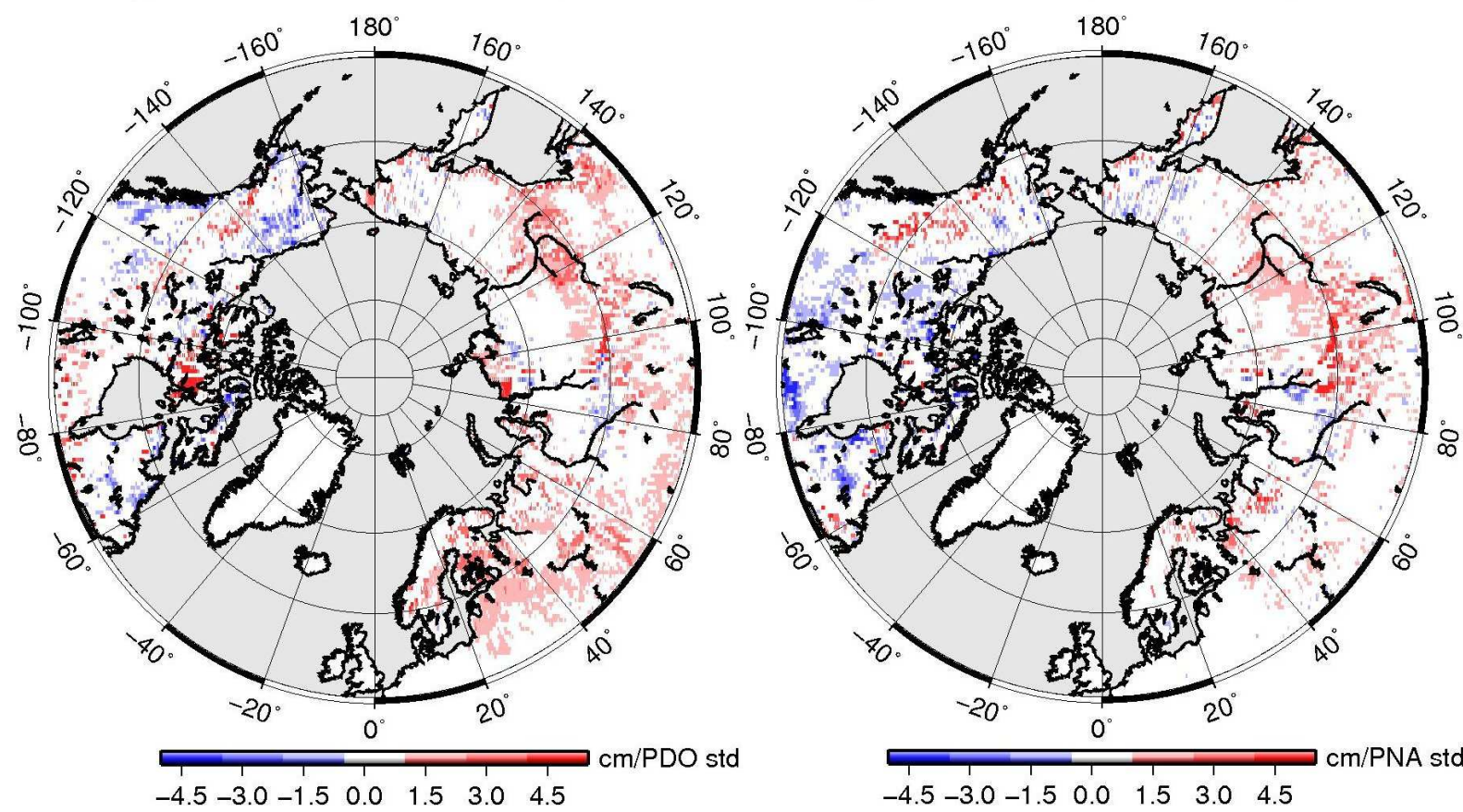

716

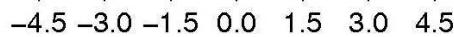

